\title{
CHARACTERIZATION OF BIOGENIC, INTERMEDIATE AND PHYSICOGENIC SOIL AGGREGATES OF AREAS IN THE BRAZILIAN ATLANTIC FOREST ${ }^{1}$
}

\author{
JÚLIO CÉSAR FEITOSA FERNANDES ${ }^{2 *}$, MARCOS GERVASIO PEREIRA ${ }^{2}$, EDUARDO CARVALHO DA SILVA \\ $\mathrm{NETO}^{2}$, THAÍS DE ANDRADE CORRÊA NETO ${ }^{2}$
}

\begin{abstract}
Aggregate formation and stability are related to soil quality, contributing significantly to the carbon storage and nutrient maintenance capacities of the soil. Soil aggregates are formed by two different process: physicogenic, related to moistening and drying cycles and input of organic matter; and biogenic, related to the action of macrofauna organisms and roots. The objective this work was to classify aggregates according to their formation process, quantify and compare organic carbon contents in humic substances and assess the stability of aggregates formed by different processes, in areas with different coverage in the Mid Paraiba Valley, Pinheiral, State of Rio de Janeiro, Brazil. Aggregated soil samples were collected at a depth of 0-10 cm, in a Cambisol (Cambissolo Háplico Tb Distrófico) under four plant covers: secondary forest in advanced (SFAS), medium (SFMS) and initial (SFIS) successional stages and managed mixed pasture (MMP). Aggregates were classified and identified into three morphological classes (physicogenic, biogenic and intermediate). The variables evaluated were mean weight diameter (MWD) and geometric mean diameter (GMD) of aggregates, chemical fractions of organic matter, total organic carbon (TOC) and humic substances: humin (C-HUM) humic acid (C-FAH) and fulvic acid (C-FAF). Biogenic aggregates were found in smaller quantities and showed higher TOC, C-HUM and C-FAH, compared to intermediate and physicogenic aggregates. Thus, biogenic aggregates have potential to be used as soil quality indicators for structured environments, which are able to maintain its intrinsic formation processes.
\end{abstract}

Keywords: Aggregate morphology. Forest fragments. Organic carbon. Humic substances.

\section{CARACTERIZAÇÃO DE AGREGADOS BIOGÊNICOS, INTERMEDIÁRIOS E FISIOGÊNICOS EM ÁREAS SOB DOMÍNIO DE MATA ATLÂNTICA}

RESUMO - A formação e estabilidade de agregados estão intimamente relacionadas à qualidade do solo, contribuindo de maneira significativa na capacidade de estocar carbono e manutenção de nutrientes no solo. Os agregados do solo são formados por duas vias distintas: a fisiogênica, relacionada a ciclos de umedecimento e/ ou secagem e adição de matéria orgânica e a biogênica associada à ação dos organismos da macrofauna e de raízes. Neste estudo, objetivou-se separar os agregados conforme a via de formação e, posteriormente, quantificar e comparar os teores de carbono orgânico das substâncias húmicas e a estabilidade de agregados formados por diferentes vias e coberturas vegetais, na região do Médio Vale do Paraiba Fluminense, Pinheiral (RJ). Foram coletadas amostras indeformadas de solo na profundidade de 0-10 cm, em um Cambissolo Háplico Tb Distrófico, sob quatro coberturas vegetais: floresta secundária em diferentes estádios sucessionais avançado (FSEA); médio (FSEM); inicial (FSEI) e uma área de pasto misto manejado (PMM). Os agregados foram separados e identificados em três classes morfológicas (fisiogênica, biogênica e intermediária). Posteriormente, foram determinados o diâmetro médio ponderado (DMP) e geométrico (DMG) dos agregados, fracionamento químico da matéria orgânica e quantificação dos teores de carbono orgânico total (COT) e das substâncias húmicas: humina (C-HUM), ácido húmico (C-FAH) e ácido fúlvico (C-FAF). Os agregados biogênicos foram encontrados em menor quantidade e apresentaram maiores teores de COT, C-HUM, C-FAH em comparação aos agregados intermediários e fisiogênicos. Dessa forma, os agregados biogênicos têm potencial para serem enquadrados como indicadores de qualidade do solo, associados a ambientes mais estruturados, capazes de manter os processos intrínsecos a sua formação.

Palavras-chave: Morfologia de agregados. Fragmentos Florestais. Carbono orgânico. Substâncias húmicas.

\footnotetext{
*Corresponding author

${ }^{1}$ Received for publication in 03/29/2015; accepted in 06/16/2016.

Paper extracted from the master dissertation of the first author.

${ }^{2}$ Department of Soils, Universidade Federal Rural do Rio de Janeiro, Seropédica, RJ, Brazil; julionrtfeitosa@yahoo.com.br, mgervasiopereira01@gmail.com, netocseduardo@gmail.com, tacneto@gmail.com.
} 


\section{INTRODUCTION}

The Brazilian Atlantic Forest originally covered approximately 1.3 million $\mathrm{km}^{2}$ of a wide longitudinal band from the Northeast to the South region of the country. Several economic cycles were developed in its extent since its colonization, resulting in loss of almost all original forest and a continuous deforestation and fragmentation of forest remnants, putting the Brazilian Atlantic forest among the most threatened ecosystems in the world. This forest is distributed throughout 17 Brazilian states and today is represented by $7.9 \%$ of its total original area (FUNDAÇÃO SOS MATA ATLÂNTICA/ INPE, 2011).

The removal of the original vegetation coverage and implementation of agricultural crops with inadequate management practices cause an unbalance between soil and environment, limiting the agricultural use of the soil and making it more susceptible to degradation (CARVALHO FILHO et al., 2009; RICHART et al., 2005). Non-conservationist farming practices reduce the soil organic matter content due to weather exposure and subsequent oxidation, causing a decrease in aggregates stability in the soil surface layer, making it more susceptible to erosion (FERREIRA; FILHO; FERREIRA, 2010).

The aggregation process consists of the union of unit particles, which bound forming microaggregates after numerous bio-physicochemical cycles (TISDALL; OADES, 1982). This formation is called pedogenetic or physicogenic and depends on many characteristics of the soil, such as content and type of clay, polyvalent cations, oxides and hydroxides of iron, aluminum and manganese, organic matter, root exudates, compounds from microbial metabolism and compressive action of roots and hyphae. The organic matter, oxides and hydroxides are cementing agents for singly particles and formed aggregates. The wetting and drying cycles are also important environmental processes influencing the genesis of soil aggregates (CARVALHO, 1991; BASTOS et al., 2005)

Soil aggregates are formed also by alternative genetic processes, such as the biogenic, which can be from feces of the soil macrofauna, and is a more rapid formation process compared to the first (MELLO; CÉCILLON; BRUN, 2008).

Impacts on soil environment and biological activity result in changes in biogenic and physicogenic aggregate formation (PULLEMAN; MARINISSEN, 2004). Thus, analysis on aggregate stability has been used as indicator of soil physical quality, since it is sensitive to changes depending on the management practices adopted. However, few studies on the genesis of different types of aggregates are found, as well as on the influence of organisms (flora and fauna) in their formation process. Studies on the genesis of different types of aggregates produce information on their dynamics and related processes and can also qualify them as soil quality indicators. Thus, the objective of this work was to analyze the aggregates formed by different processes (biogenic and physicogenic) in areas with different coverage in the Mid Paraiba Valley, State of Rio de Janeiro, Brazil.

\section{MATERIAL AND METHODS}

The study was conducted in Pinheiral, Mid Paraiba Valley, State of Rio de Janeiro, Brazil, in the Ribeirao Cachimbal sub-basin, Paraiba do Sul river basin $\left(22^{\circ} 29^{\prime} 03^{\prime \prime}\right.$ to $22^{\circ} 35^{\prime} 27^{\prime} \mathrm{S}$ and $43^{\circ} 54^{\prime} 49^{\prime \prime}$ to $44^{\circ} 04^{\prime} 05^{\prime \prime} \mathrm{W}$ and 360 to $720 \mathrm{~m}$ of altitude) (Figure 1). According to the Koppen classification, the region climate is Am, tropical with dry winter and rainy summer. Its annual average precipitation is $1,173 \mathrm{~mm}$ and annual average temperature is $20.9^{\circ} \mathrm{C}$. The selected areas were in the upper third position of the slope, in which the soil was classified as Cambisol - CAMBISSOLO HÁPLICO TB DISTRÓFICO (SANTOS et al., 2013).

Submontane Seasonal Semidecidual Forest areas in the Atlantic Forest biome were selected for study, which had the following successive stages: Secondary Forest Initial Stage (SFIS), Secondary Forest Medium Stage (SFMS), Secondary Forest Advanced Stage (SFAS) and Managed Mixed Pasture (MMP).

The description of the areas used for this study was performed by Menezes et al. (2010) and is shown in Table 1.

Six soil samples were collected in each area, at a depth of $0-10 \mathrm{~cm}$, in the rainy season (February/2010), and subjected to sieving in the field, using sieves with mesh of 9.70 and $8.00 \mathrm{~mm}$. The aggregates retained on the $8.00 \mathrm{~mm}$ sieve were manually classified, according to the morphological classes described by Bullock et al. (1985), with a stereomicroscope. Three aggregate classes were: physicogenic, those that have angular shapes; biogenic, those that have rounded shapes, originated from intestinal tracts of the soil macrofauna, mainly Oligochaeta, and those in which the root activity is apparent; and intermediate, aggregates that have undefined formation and may be biogenic that lost their rounded shape due to aging, or physicogenic welded with a small coprolite. 


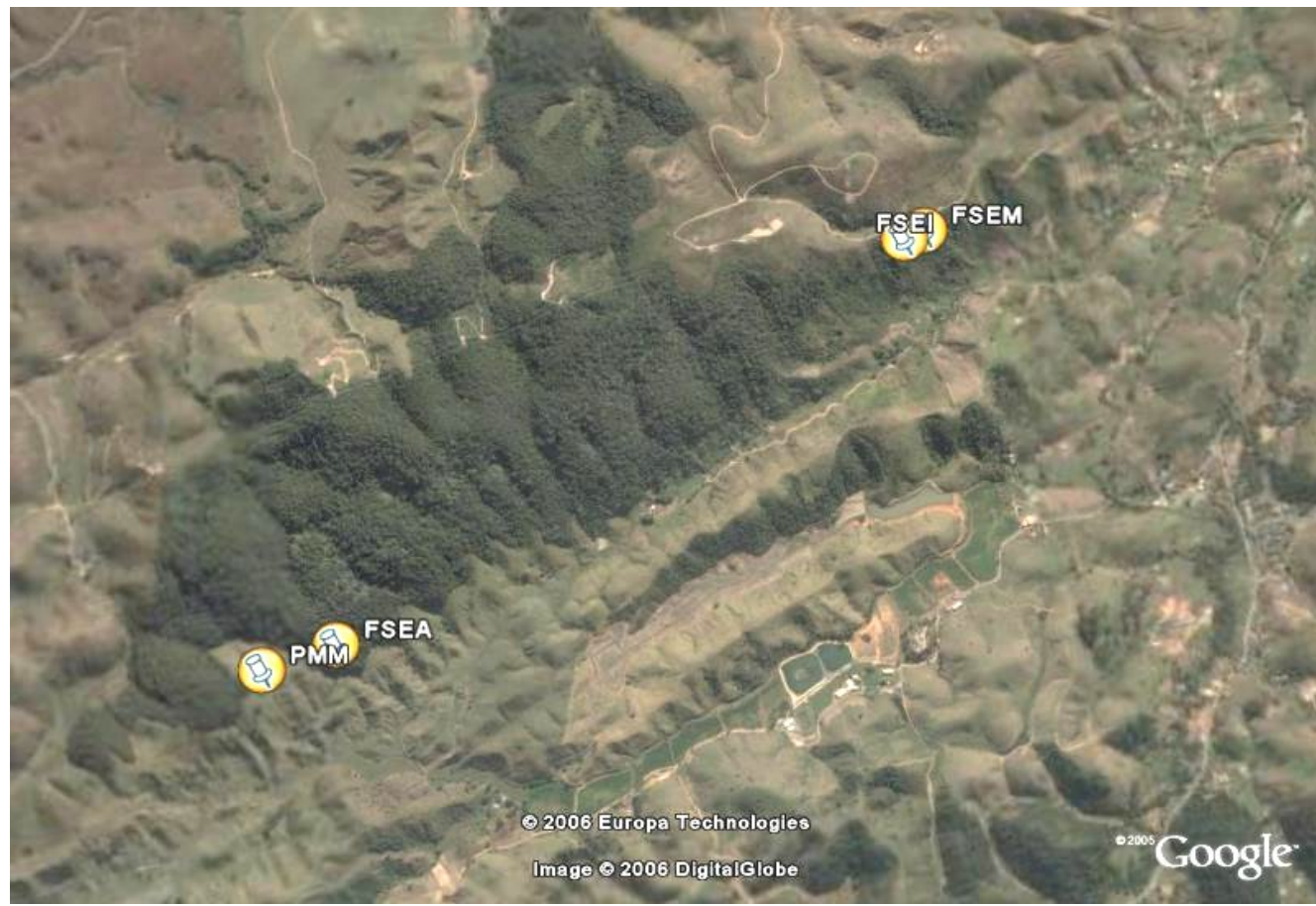

Figure 1. Location of the studied sites, Pinheiral, Rio de Janeiro, Brazil. (Source: Google Maps).

Table 1. Floristic characterization of the study areas under forest fragments and pasture.

\begin{tabular}{clc}
\hline Study areas & \multicolumn{1}{c}{ Description } & Families \\
\hline \multirow{5}{*}{ SFIS } & $\begin{array}{l}\text { Herbaceous/shrubby physiognomy, with predominance } \\
\text { of Heliophila species, few woody species (less than } \\
\text { twenty per ha), with low diameter at breast height } \\
\text { (DBH) (average less than } 5 \mathrm{~cm} \text { ) and height (average } \\
\text { less than 5 m). The community age were 0 to 10 years. }\end{array}$ & $\begin{array}{c}\text { Annonaceae, Melastomataceae, Spiranunaceae, } \\
\text { Thelypteridaceae, } \\
\text { Urticaceae. }\end{array}$ \\
\hline \multirow{5}{*}{ SFMS } & $\begin{array}{l}\text { Shrub/tree physiognomy, with initial stratification, } \\
\text { shading species emerging, individuals with DBHs and } \\
\text { heights higher than the SFIS area, emergence of lower }\end{array}$ & $\begin{array}{c}\text { Anacardiaceae, Lecytidaceae, Melastomataceae, } \\
\text { Moraceae, Myrsinaceae, Myrtaceae, Rubiaceae, } \\
\text { Sapindaceae, Siparmaceae, Urticaceae. }\end{array}$ \\
& $\begin{array}{l}\text { woods and woody lianas. The community age were 11 } \\
\text { to 25 years. }\end{array}$ & $\begin{array}{c}\text { Anacardiaceae, Bignoniaceae, Burceraceae, } \\
\text { Fabaceae, Erytroxilaceae, Lauraceae, }\end{array}$ \\
& $\begin{array}{l}\text { Considered the oldest fragment of the Ribeirao } \\
\text { Cachimbal sub-basin. Arboreal physiognomy with } \\
\text { emergent trees, understory apparent formed by shade- } \\
\text { tolerant species, great diversity of woody species with } \\
\text { higher DBH and height, and abundant lianas and } \\
\text { epiphytes. The community age was over 25 years. }\end{array}$ & $\begin{array}{c}\text { Myrtaceae, Nyctaginaceae, Polygonaceae, } \\
\text { Rubiaceae, Sapindaceae, Siparumaceae, } \\
\text { Solanaceae e Urticaceae. }\end{array}$ \\
\hline
\end{tabular}

Spontaneous pasture area exploited since 1950, formed in the 1990s with Brachiaria decumbens and

MMP maintained through annual mowing and burning. A grassy species (Paspalum notatum), known as grama-

Poaceae batatais, emerged in this landscape along the years, which now coexist with the introduced Brachiaria.

SFIS = Secondary Forest Initial Stage; SFMS = Secondary Forest Medium Stage; SFAS = Secondary Forest Advanced Stage; and MMP = Managed Mixed Pasture.

The identification of classes was performed by weighing $100 \mathrm{~g}$ of aggregates from each plot and replication and determining their relative mass contribution. After classification, the stability of aggregates in water was evaluated (KEMPER; CHEPELI, 1965), and the aggregate indices mean weight diameter (MWD) and geometric mean diameter (GMD) were calculate. Part of the aggregates was disaggregated and sieved in a 2.00 $\mathrm{mm}$ mesh sieve, to quantify the total organic carbon (TOC), according to the method of Yeomans and Bremner (1988), and chemical fractions of the organic matter in the aggregates (BENITES et al., 2003), which were the humin (HUM), humic acid (FAH), and fulvic acids (FAF).

The carbon content in these fractions were

Rev. Caatinga, Mossoró, v. 30, n. 1, p. 59 - 67, jan. - mar., 2017 
then determined (C-HUM C-FAH and C-FAF), as well as the relationships $\mathrm{C}-\mathrm{FAH} / \mathrm{C}-\mathrm{FAF}$ and $\mathrm{C}-\mathrm{AE} / \mathrm{C}-\mathrm{HUM}$, where C-EA is the organic carbon determined in alkaline extract (humic + fulvic acids).

The data were assessed for normality (Lillefors test) and homogeneity (Cochran and Barttlet test) and then subjected to analysis of variance by the $F$ test. The mean values, when significant, were compared by the Bonferroni t test at $5 \%$.

\section{RESULTS AND DISCUSSION}

All areas evaluated received greater contribution of the physicogenic morphological class, followed by the intermediate and biogenic classes (Table 2). This pattern indicates that, although the biogenic aggregation is faster in formation, it requires conditions of greater availability of resources, such as climate, chemical and physical soil properties, and especially quantity and quality of plant material in the soil (COQ et al., 2007). This resources allow the soil fauna activity, which are the main precursors of biogenic aggregates, and make this processes more sensitive to ecosystem changes (JOUQUET et al., 2006).

Table 2. Distribution (\%) of aggregates on the different morphological classes.

\begin{tabular}{ccccc}
\hline \multirow{2}{*}{ Study areas } & \multicolumn{5}{c}{$\%$} & CV2 (\%) \\
\cline { 2 - 5 } & Physicogenic & Intermediate & Biogenic & 4.18 \\
SFAS & $40.70 \mathrm{Aa}$ & $32.26 \mathrm{Bc}$ & $26.78 \mathrm{Ca}$ & 1.79 \\
SFMS & $41.28 \mathrm{Aa}$ & $36.68 \mathrm{Bb}$ & $24.23 \mathrm{Cb}$ & 4.10 \\
SFIS & $36.29 \mathrm{Bb}$ & $40.28 \mathrm{Aa}$ & $23.07 \mathrm{Cb}$ & 5.63 \\
MMP & $42.19 \mathrm{Aa}$ & $28.20 \mathrm{Bd}$ & $28.77 \mathrm{Ba}$ & \\
CV1 (\%) & 3.67 & 3.93 & 5.16 & \\
\hline
\end{tabular}

Averages from six replications. Values followed by the same upper case letters in the same line or same lower case in the same column do not differ by Bonferroni $t$ test $(\mathrm{p}<0.05)$. SFIS $=$ Secondary Forest Initial Stage; SFMS $=$ Secondary Forest Medium Stage; SFAS $=$ Secondary Forest Advanced Stage; and MMP = Managed Mixed

Pasture. CV1: coefficient of variation of morphological classes; CV2: coefficient of variation of areas of study.

The greatest amount of biogenic aggregates was found in the MMP and SFAS areas, which may be related to an intense rhizodeposition process (MMP) and better trophic conditions due their litterfall cycling (SFAS), and also due to a longer use time of the areas. Menezes et al. (2009) characterized soil macroinvertebrates in this same areas and found prevalence of Oligochaeta in MMP area. They attributed this result to the higher density of roots of grass species, which contributed to the greater availability of organic matter and provide a better environment in this area.

A decreasing pattern of contribution of the biogenic aggregate class with the successional progress of the forest fragments was noted, i.e., from the SFAS to the SFIS area. This result can be attributed to the plant growth along the secondary succession process, which promotes a combination of litterfall and soil macrofauna, resulting in a heterogeneous distribution of soil components (SILVA et al., 2006).

The SFIS area had the highest percentage of intermediate and smaller amount of physicogenic and biogenic aggregates, although had not statistically differed from SFMS area regarding the biogenic aggregates. The increase in the amount of aggregates from the intermediate class is probably due to changes in the aggregate form with time or welding of aggregates, confirming the significant carbon content found in these areas. The physicogenic morphological class were the most expressive in the MMP area. This result is attributed to a greater alternation of wetting and drying cycles, since pasture have lower maintenance of soil moisture compared to forest areas.

The TOC (Table 3) presented statistical difference between the areas only for the physicogenic aggregates, which had highest values in the SFMS and SFIS areas. These areas were more recent formations, thus they had contributed to the organic matter content from the shrubby material and rhizodeposition of grasses from the pasture from which these areas were formed.

The lower TOC aggregates was related to the physicogenic aggregates in the SFAS area, which had significant litterfall production, as assessed by Menezes et al. (2010). The high amount of litterfall in SFAS could have favored the soil fauna development and consequently a higher TOC in the biogenic aggregates. Moreover, this type of aggregate contributes more efficiently to physical protection of soil organic matter, reducing the decomposition rate and increasing the carbon sequestration potential (SILVA NETO et al., 2010). 
Table 3. Total organic carbon and carbon of humic compounds $\left(\mathrm{g} \mathrm{kg}^{-1}\right)$ and the relationships C-FAH/C-FAF, $\mathrm{C}-\mathrm{HUM} / \mathrm{C}-\mathrm{EA}$ of the different aggregate classes (AC) and study areas.

\begin{tabular}{|c|c|c|c|c|c|c|}
\hline \multirow{2}{*}{$\mathrm{AC}$} & & \multicolumn{5}{|c|}{ Study areas } \\
\hline & \multirow{4}{*}{ TOC } & SFAS & SFMS & SFIS & MMP & CV2 (\%) \\
\hline $\mathrm{P}$ & & $19.68 \mathrm{ABa}$ & $20.61 \mathrm{Ab}$ & $21.15 \mathrm{Ab}$ & $17.12 \mathrm{Bb}$ & 6.54 \\
\hline I & & $20.55 \mathrm{Aa}$ & $21.21 \mathrm{Ab}$ & $20.92 \mathrm{Ab}$ & 19.01 Aab & 8.90 \\
\hline B & & $22.33 \mathrm{Aa}$ & $25.60 \mathrm{Aa}$ & $24.74 \mathrm{Aa}$ & $20.28 \mathrm{Aa}$ & 10.31 \\
\hline & CV1 (\%) & 12.91 & 8.35 & 6.73 & 5.90 & \\
\hline $\bar{P}$ & \multirow{3}{*}{ C-FAF } & $3.62 \mathrm{Ab}$ & $3.45 \mathrm{Aa}$ & $3.17 \mathrm{Ba}$ & $2.76 \mathrm{Cb}$ & 2.72 \\
\hline I & & $3.95 \mathrm{Aab}$ & $3.44 \mathrm{Ba}$ & $3.07 \mathrm{Ca}$ & $3.05 \mathrm{Ca}$ & 4.59 \\
\hline B & & $4.07 \mathrm{Aa}$ & $3.48 \mathrm{Ba}$ & $3.10 \mathrm{Ca}$ & $2.77 \mathrm{Db}$ & 4.27 \\
\hline & CV1 (\%) & 4.81 & 3.21 & 3.02 & 4.11 & \\
\hline $\mathrm{P}$ & \multirow{3}{*}{ C-FAH } & $4.05 \mathrm{Aa}$ & $3.49 \mathrm{Bb}$ & $3.28 \mathrm{Bb}$ & $3.26 \mathrm{Ba}$ & 6.18 \\
\hline I & & $3.66 \mathrm{Aa}$ & 3.57 Aab & $2.81 \mathrm{Bc}$ & $3.25 \mathrm{ABa}$ & 8.18 \\
\hline $\mathrm{B}$ & & $3.95 \mathrm{Aa}$ & $3.95 \mathrm{Aa}$ & $3.89 \mathrm{Aa}$ & $3.27 \mathrm{Ba}$ & 5.69 \\
\hline \multicolumn{7}{|c|}{ CV1 } \\
\hline $\mathrm{P}$ & \multirow{3}{*}{ C-HUM } & $12.70 \mathrm{Bb}$ & $12.51 \mathrm{Bb}$ & $14.00 \mathrm{Ac}$ & $13.21 \mathrm{ABb}$ & 3.28 \\
\hline I & & 14.20 Aab & $13.21 \mathrm{Ab}$ & $15.55 \mathrm{Ab}$ & $13.39 \mathrm{Ab}$ & 7.50 \\
\hline $\mathrm{B}$ & & $15.81 \mathrm{ABa}$ & $16.55 \mathrm{Aa}$ & $17.03 \mathrm{Aa}$ & $13.95 \mathrm{Ba}$ & 6.43 \\
\hline & CV1(\%) & 6.39 & 9.48 & 3.76 & 0.95 & \\
\hline $\mathrm{P}$ & \multirow{3}{*}{ C-FAH/C-FAF } & $1.10 \mathrm{Aa}$ & $0.96 \mathrm{Bb}$ & $1.01 \mathrm{ABb}$ & $1.13 \mathrm{Aab}$ & 5.66 \\
\hline I & & $0.94 \mathrm{Aa}$ & $1.04 \mathrm{Aa}$ & $0.96 \mathrm{Ab}$ & $1.04 \mathrm{Ab}$ & 6.65 \\
\hline $\mathrm{B}$ & & $1.01 \mathrm{Ba}$ & $1.08 \mathrm{ABa}$ & $1.23 \mathrm{Aa}$ & $1.23 \mathrm{Aa}$ & 6.45 \\
\hline & CV1 (\%) & 8.82 & 3.17 & 5.53 & 6.32 & \\
\hline $\mathrm{P}$ & \multirow{3}{*}{ C-EA/C-HUM } & $0.63 \mathrm{Aa}$ & $0.52 \mathrm{Ba}$ & $0.45 \mathrm{Ca}$ & $0.45 \mathrm{Ca}$ & 6.06 \\
\hline I & & $0.59 \mathrm{Aa}$ & $0.54 \mathrm{Aa}$ & $0.38 \mathrm{Cb}$ & $0.47 \mathrm{Ba}$ & 4.35 \\
\hline B & & $0.52 \mathrm{Ab}$ & $0.46 \mathrm{Bb}$ & $0.40 \mathrm{Cb}$ & $0.46 \mathrm{Ba}$ & 4.08 \\
\hline & CV1 (\%) & 5.57 & 6.40 & 4.11 & 3.32 & \\
\hline
\end{tabular}

Averages from six replications. Values followed by the same upper case letters in the same line or same lower case in the same column do not differ by Bonferroni t test $(\mathrm{p}<0.05) . \mathrm{P}=$ physicogenic, $\mathrm{I}=$ intermediate and $\mathrm{B}=$ biogenic. SFIS $=$ Secondary Forest Initial Stage; SFMS = Secondary Forest Medium Stage; SFAS = Secondary Forest Advanced Stage; and MMP = Managed Mixed Pasture. CV1: coefficient of variation of morphological classes; CV2: coefficient of variation of areas of study.

Biogenic aggregates had an enrichment of organic carbon compared to physicogenic aggregates in all areas (SFAS, 13.5; SFMS, 24.2; SFIS, 17.0 and MMP 18.5\%). Bossuyt et al. (2005) found similar results, with biogenic aggregates enrichment of organic carbon of $22 \%$ compared to physicogenic aggregates. According to Brown et al. (2000), even in inhabiting subsurface layers of the soil, with low content of organic matter, earthworms can increase the decomposition of stable forms of the carbon ingested, due to moistening and addition of mucus of mutualistic microorganisms of their digestive system. This process increases mineralization rates in coprolites, which, according to James and Brown (2008), constitute important sources of nutrients for plants.

The carbon of humic substances of all evaluated areas had larger percentage related to the humin fraction $(60.71$ to $77.16 \%)$, followed by the humic acid (13.44 to $20.58 \%)$ and fulvic acid (12.52 to $19.20 \%$ ) fractions. The greater carbon content in humin form implies a higher moisture retention, a better soil aggregation and a greater retention of cations (SOUZA; MELO, 2003).

The higher levels of C-HUM were found, in general, in biogenic aggregates in forest areas (SFIS, SFMS and SFAS), with a decreasing pattern in the C-HUM content with the succession progress, which may be due to the most diverse nature of the substrate forming their litterfall, influencing positively in the decomposition community activity and thus benefiting the process of decomposition of organic matter (BARLOW et al., 2007).

The SFAS and SFMS areas had higher C-FAF content compared to the SFIS and MMP areas for all aggregate classes. The higher values of $\mathrm{C}-\mathrm{FAH}$ fraction were found in physicogenic aggregates in the SFAS area. These results may be related to higher litterfall production in these areas. Menezes et al. (2010) found in these same areas, higher litterfall production in the SFAS (11 $\mathrm{Mg} \mathrm{ha}^{-1} \mathrm{ano}^{-1}$ ) and SFMS (7.4 $\left.\mathrm{Mg} \mathrm{ha}^{-1} \mathrm{ano}^{-1}\right)$.

C-FAH/C-FAF and C-AE/C-HUM have been used for interpreting the results from chemical fractions of SOM, related to the condensation level of soluble organic matter (C-FAH/C-FAF) and structural stability level of the organic matter (C-AE/ C-HUM), i.e., the higher the relationship values the greater the stability (CUNHA et al., 2005).

The C-FAH content was proportionally greater than the $\mathrm{C}-\mathrm{FAF}$ content in all areas, presenting values greater than 1 for C-FAH/C-FAF, with the highest values for this relationship in the SFAS and MMP areas for physicogenic aggregates and in SFIS and MMP areas for biogenic aggregates. Indicating that these aggregate classes were 
associated with more stable organic material.

The SFIS and MMP areas had the lowest values of $\mathrm{C}$-AE/C-HUM, denoting a greater preservation of the organic material, which results in a higher proportion of stable fractions and greater structural stability, i.e., a more advanced humification stage.

C-HUM content (17.03 $\mathrm{g} \mathrm{kg}^{-1}$ ) was greater in the SFIS area, confirming the values of the C-HUM/ C-EA (2.51), and smaller in the MMP area (13.95 $\left.\mathrm{g} \mathrm{kg}^{-1}\right)$. However, the contribution of the carbon in the humin fraction compared to TOC (Figure 2) for the MMP area (68.79\%) had similar percentages to those found in the SFIS area (68.84\%), with higher percentages for biogenic aggregates in the SFAS area $(70.80 \%)$. This result denotes favorable conditions to microbial activity (temperature, moisture, aeration and nutrient availability), mineralization processes and humus synthesis, since those are predominantly from microbial origins (LONGO; ESPÍNDOLA, 2000).

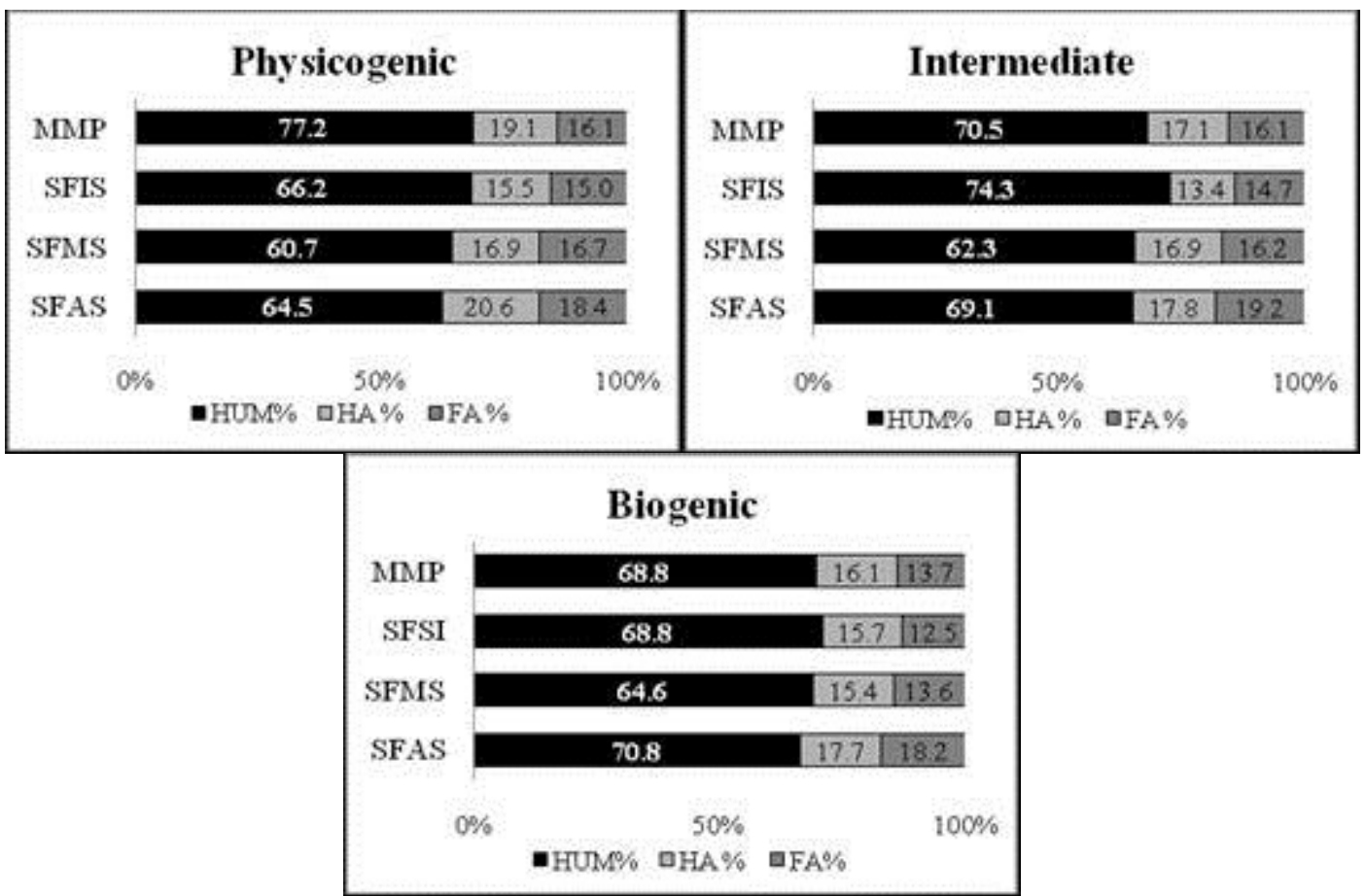

Figure 2. Relative distribution (\%) of humin fractions (HUM), humic acid (HA) and fulvic acid (FA) in relation to the total organic carbon (TOC) in the aggregate classes physicogenic, intermediate and biogenic in Secondary Forest Initial Stage (SFIS), Secondary Forest Medium Stage (SFMS), Secondary Forest Advanced Stage (SFAS) and Managed Mixed Pasture (MMP).

Earthworms have a direct effect on biogeochemical cycling through the rearrangement of soil particles, changing the pore distribution and size, and act in soil fragmentation and incorporation of plant debris, increasing the availability of resources for microorganisms (JOUQUET et al., 2006), positively affecting the ecology of humification, as observed by the highest C-HUM content in aggregates from biological processes.

The biogenic aggregates had higher $\mathrm{C}-\mathrm{FAH}$ content in the SFMS and SFIS areas and higher values of C-FAH/C-FAF. This results may be due to the favorable physical and chemical conditions to biological activity, increasing the intensity of humification process, thus contributing to the formation of more condensed alkali-soluble humic substances (humic acids) in these aggregates (STEVENSON, 1994).
The lowest values of MWD and GMD (Table 4) were found in the SFAS area in all aggregate classes. The SFIS area stood out among the areas evaluated with the highest MWD values related to biogenic aggregates and higher DMG values related to the intermediate class.

The results of the SFIS area may be related to its recent conversion, due to the abandonment of the pasture formerly established, which started the forest succession process, having a contribution to the input of organic matter from the grass rhizodeposition.

The aggregate weight (Figure 3) presented a pattern similar to that found for the MWD and GMD values, with the greatest aggregate weight in class of larger diameter. Therefore, the greater the stability in water of the $2.00 \mathrm{~mm}$ aggregate class, the greater the MWD, GMD and aggregate weight. 
Table 4. Mean weight diameter (MWD) and geometric mean diameter (GMD) (mm) of different aggregate classes (AC) and study areas.

\begin{tabular}{ccccccc}
\hline \multirow{2}{*}{ CA } & \multicolumn{5}{c}{ Study areas } \\
\cline { 3 - 6 } & & SFAS & SFMS & SFIS & MMP & CV2 (\%) \\
\cline { 3 - 6 } Physicogenic & \multirow{2}{*}{ MWD } & $4.12 \mathrm{Bb}$ & $4.87 \mathrm{Aa}$ & $4.99 \mathrm{Aa}$ & $4.82 \mathrm{Aa}$ & 2.01 \\
Intermediate & & $4.39 \mathrm{Ba}$ & $4.91 \mathrm{Aa}$ & $4.95 \mathrm{Aa}$ & $4.85 \mathrm{Aa}$ & 2.00 \\
Biogenic & $4.42 \mathrm{Ca}$ & $4.89 \mathrm{Ba}$ & $4.96 \mathrm{Aa}$ & $4.85 \mathrm{Ba}$ & 0.79 \\
\hline CV1(\%) & & 2.85 & 1.30 & 0.41 & 0.63 & \\
\hline Physicogenic & GMD & $3.13 \mathrm{Cb}$ & $4.59 \mathrm{ABa}$ & $4.84 \mathrm{Aa}$ & $4.32 \mathrm{Ba}$ & 4.86 \\
Intermediate & & $3.59 \mathrm{Ca}$ & $4.56 \mathrm{Ba}$ & $4.84 \mathrm{Aa}$ & $4.39 \mathrm{Ba}$ & 2.53 \\
Biogenic & $3.67 \mathrm{Ca}$ & $4.58 \mathrm{ABa}$ & $4.81 \mathrm{Aa}$ & $4.47 \mathrm{Ba}$ & 2.81 \\
\hline CV1(\%) & & 5.16 & 4.80 & 0.62 & 2.16 & \\
\hline
\end{tabular}

Averages from six replications. Values followed by the same upper case letters in the same line or same lower case in the same column do not differ by Bonferroni t test $(\mathrm{p}<0.05)$. SFIS = Secondary Forest Initial Stage; SFMS = Secondary Forest Medium Stage; SFAS $=$ Secondary Forest Advanced Stage; and MMP = Managed Mixed Pasture. CV1: coefficient of variation of morphological classes; CV2: coefficient of variation of areas of study.

The SFAS area had higher weight of smaller aggregates, probably due to its longer land use time compared to the other areas and its higher SOM humification level (seen in lower C-AE/C-HUM), which favors the maintenance of stability of stable (micro) aggregates, while the root activity benefited the formation of macroaggregates in the other areas, resulting in a higher (macro) aggregate weight.
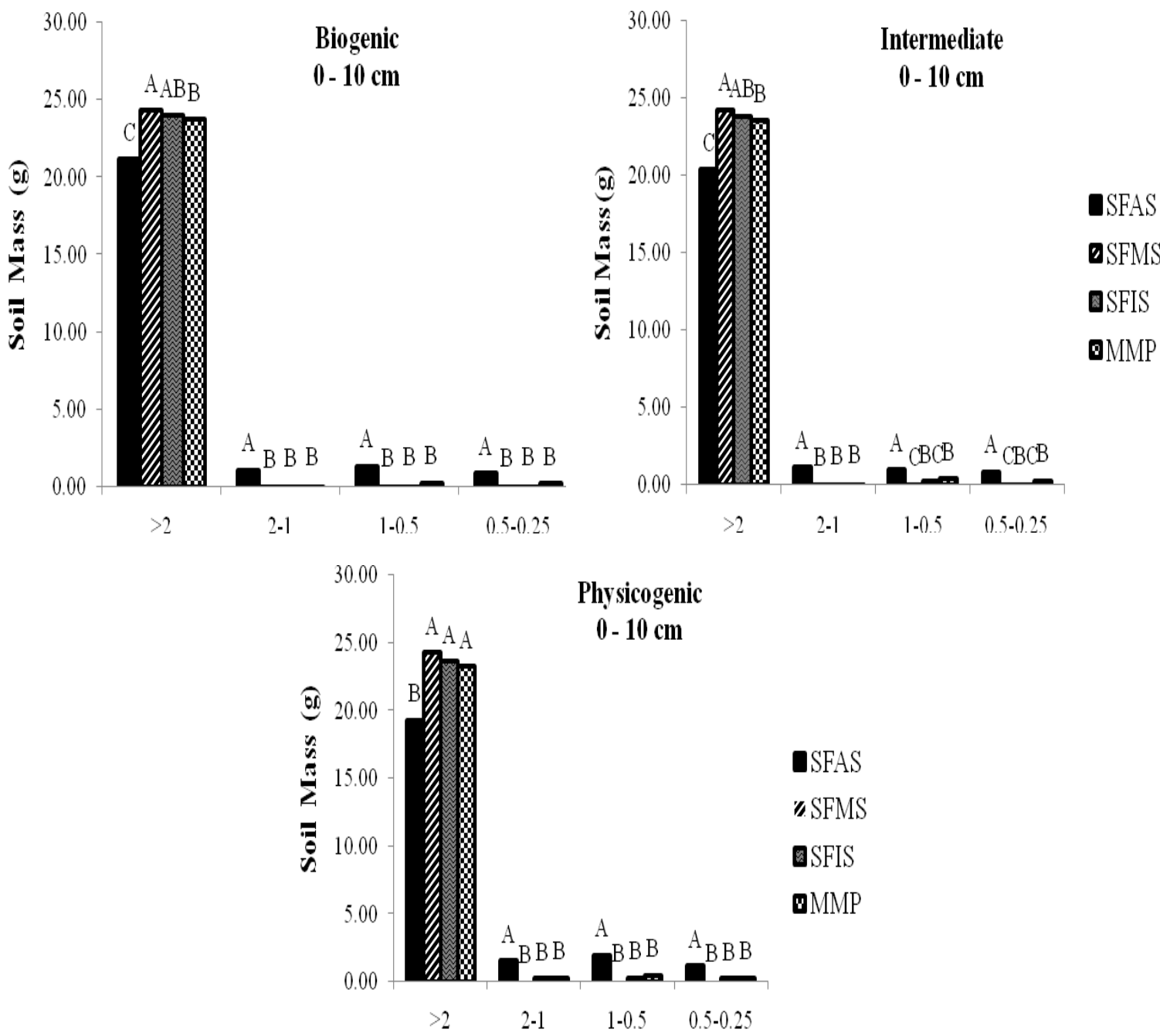

Aggregate Size Class (mm)

Figure 3. Distribution of water-stable aggregates by size classes in the different sites of study. Values followed by the same letter within each class do not differ significantly by Bonferroni t test at $5 \%(p<0.05)$. 
The morphological classes presented statistical difference only in the SFAS area, in which the biogenic class presented the highest MWD and GMD values, confirming the C-HUM values (Table 2), although it did not statistically deferred from the intermediate class. According Oyedele et al. (2006), the process soil and organic waste intake by earthworms leads to the formation of coprolites, biogenic aggregates which are stable and resistant to soil cycles of wetting and drying.

Silva Neto et al. (2010) compared physical and chemical attributes of pedogenetic and biogenic (coprolites) aggregates of different soil classes of state of Paraiba, and found higher MWD values in biogenic aggregates in all soil classes. They attributed this result to the higher proportions of clay, cations and organic matter of coprolites, which favors more intense interactions compared to pedogenic aggregates (physicogenic).

\section{CONCLUSIONS}

SFIS and SFMS areas have higher values of TOC for physicogenic aggregates, resulting in higher values of MWD and GMD;

The distribution of aggregates in SFAS areas, regarding their stability, evaluated by MWD and GMD, have the following pattern: biogenic $>$ physicogenic $>$ intermediaries;

Biogenic aggregates have higher increase of TOC, C-HUM and C-FAH compared to physicogenic;

The significant differences found in the physical and chemical attributes evaluated indicate that the morphological classification is effective for characterize the established formation processes.

\section{REFERENCES}

BARLOW, A. J. et al. Litter fall and decomposition in primary, secondary and plantation forests in the Brazilian Amazon. Forest Ecology and Management, Kidlington, v. 247, n. 1, p. 91-97, 2007.

BASTOS, R. S. et al. Formação e estabilização de agregados do solo influenciados por ciclos de umedecimento e secagem após adição de compostos orgânicos com diferentes características hidrofóbicas. Revista Brasileira de Ciência do Solo, Viçosa, v. 29, n. 1, p. 21-31, 2005.

BENITES, V. M.; MADARI, B.; MACHADO, P. L. $O$. A. Extração e fracionamento quantitativo de substâncias húmicas do solo: um procedimento simplificado de baixo custo. 1. ed. Rio de Janeiro: Embrapa, 2003. 7 p. (Comunicado Técnico, 16).
BOSSUYT, H.; SIX, J.; HENDRIX, P. F. Protection of soil carbon by microaggregates within earthworm casts. Soil Biology \& Biochemistry, Oxford, v. 37, n. 2, p. 251-258, 2005.

BROWN, G. G.; BAROIS, I.; LAVELLE, P. Regulation of soil organic matter dynamics and microbial activity in the drilosphere and role of interactions with other edaphic functional domains. European Journal of Soil Biology, Oxford, v. 36, n. 3, p. 177-198, 2000.

BULlOCK, P. et al. Handbook for Soil Thin Section Description. Albrighton, England: Waine Research Publications, 1985. 152 p.

CARVALHO, A. F. Emprego da agitação horizontal na avaliação da estabilidade de agregados de cinco solos da região sudeste. 1991. 73 f. Dissertação (Mestrado em Agronomia/Solos e Nutrição de Plantas) - Universidade Federal de Viçosa, Viçosa, 1991.

CARVALHO FILHO, A. et al. Qualidade física de um Latossolo Vermelho férrico sob sistemas de uso e manejo. Bioscience Journal, Uberlândia, v. 25, n. 6, p. 43-51, 2009.

COQ, S. et al. Earthworm activity affects soil aggregation and organic matter dynamics according to the quality and localization of crop residues - An experimental study (Madagascar). Soil biology \& biochemistry, Oxford, v. 39, n. 8, p. 2119-2128, 2007.

CUNHA, T. J. F. et al. Fracionamento da matéria orgânica humificada de solos brasileiros. In: Canellas, L. P.; Santos, G. A. (Eds.). Humosfera: tratado preliminar sobre a química das substancias húmicas. Campos dos Goytacazes: Universidade Estadual do Norte Fluminense, 2005. v. 1 , cap. 3 , p.54-80.

FERREIRA, R. R. M.; FILHO, J. T.; FERREIRA, V. M. Efeitos de sistemas de manejo de pastagens nas propriedades físicas do solo. Semina: Ciências Agrárias, Londrina, v. 31, n. 4, p. 913-932, 2010.

FUNDAÇÃO SOS MATA ATLÂNTICA. Instituto Nacional de Pesquisas Espaciais. Atlas dos Remanescentes florestais da Mata Atlântica e Ecossistemas Associados no Domínio da Mata Atlântica, no período de 2010 a 2011. Disponível em: $\quad<$ http://www.sosmataatlantica.org.br>. Disponível em: Acesso em: 25 jan. 2013.

JAMES, S.W.; BROWN, G. G. Ecologia e diversidade de minhocas no Brasil. In.: Moreira, F. M. S.; Siqueira, J. O.; Brussard, L. (Eds.). Biodiversidade do solo em ecossistemas 
brasileiros. Lavras: Universidade Federal de Lavras, 2008. v. 1, cap. 7, p. 192-276.

JOUQUET, P. et al. Soil invertebrates as ecosystem engineers: intended and accidental effects on soil and feedback loops. Applied Soil Ecology, Oxford, v. 32, n. 2, p. 153-164, 2006.

KEMPER, W. D.; CHEPIL, W.S. Size Distribution of Aggregation. In: BLACK, C.A. (Ed.). Methods of Soil Analysis. Madison: American Society of Agronomy, 1965. p. 499-510.

LONGO, R. M.; ESPÍNDOLA, C. R. C-orgânico, Ntotal e substancias humicas sob influencia da introdução de pastagens (Brachiaria sp.) em áreas de cerrado e floresta amazônica. Revista Brasileira de Ciência do Solo, Viçosa, v. 24, n. 4, p. 723-729, 2000.

MELLO, N. A.; CÉCILLON, L.; BRUN, J. J. Formação e propriedades de Macroagregados de um solo alpino sob três tipos de vegetação nativa. In: REUNIÃO BRASILEIRA DE MANEJO E CONSERVAÇÃO DO SOLO E DA ÁGUA: NO CONTEXTO DAS MUDANÇAS AMBIENTAIS, 27, 2008. Rio de Janeiro. Anais... Rio de Janeiro: SBS, 2008. CD-ROM.

MENEZES, C. E.G.et al. Aporte e decomposição da serapilheira e produção de biomassa radicular em florestas com diferentes estágios sucessionais em Pinheiral (RJ). Revista Ciência Florestal, Santa Maria, v. 20, n. 3, p. 439-452, 2010.

MENEZES, C. E. G. et al. Macrofauna edáfica em estádios sucessionais de Floresta Estacional Semidecidual e pastagem mista em Pinheiral (RJ). Revista Brasileira de Ciência do Solo, Viçosa, v. 33, n. 6, p. 1647-1656, 2009.

OYEDELE, D. J.; SCHJONNING, P.; AMUSAN, A. A. Physicochemical properties of earthworm casts and undigested parent soil from selected sites in southwestern Nigeria. Ecological Engineering, Oxford, v. 28, n. 2, p.106-113, 2006.

PULLEMAN, M. M.; MARINISSEN, J. C. Y. Physical protection of mineralizable $\mathrm{C}$ in aggregates from longterm pasture and arable soil.Geoderma, Amsterdam, v. 120, n. 3-4, p. 273-282, 2004.

RICHART, A. et al. Compactação do solo: causas e efeitos. Semina: Ciências Agrárias, Londrina, v. 26, n. 3, p. 321-344, 2005.

SANTOS, H. G. et al. Sistema brasileiro de classificação de solos. 3. ed. Brasília, DF: Embrapa, 2013. 353 p.
SILVA, A. J. N. et al. Impact of sugarcane cultivation on soil carbon fractions, consistence limits and aggregate stability of a Yellow Latosol in Northeast Brazil. Soil \&Tillage Research, Oxford, v.94, n. 2, p. 420-424, 2006.

SILVA NETO, L. F. et al. Atributos físicos e químicos de agregados pedogênicos e de coprólitos de minhocas em diferentes classes de solos da Paraíba. Ciência Agrotecnologia, Lavras, v. 34, n. 6, p. 1365-1371, 2010.

SOUZA, W. J. O.; MELO, W. J. Matéria orgânica de um Latossolo submetido a diferentes sistemas de produção de milho. Revista Brasileira de Ciência do Solo, Lavras, v. 27, n. 6, p.1113-1122, 2003.

STEVENSON, F. J. Humus chemistry: Genesis, composition, reactions. 2. ed. New York, Willey, 1994, $496 \mathrm{p}$.

TISDALL, J. M.; OADES, J. M. Organic matter and water stable aggregates in soils. Journal of Soil Science, Oxford, v. 33, n. 2, p. 141-163, 1982.

YEOMANS, J. C.; BREMNER, J. M. A rapid and precise method for routine determination of organic carbon in soil. Communications in Soil Science and Plant Analysis, Abingdon, v. 19, n. 13, p. $1467-$ 1476, 1988. 